\title{
HUBUNGAN PERSEPSI PEMAKAIAN ALAT KONTRASEPSI DENGAN KEJADIAN UNMET NEED PADA PASANGAN USIA SUBUR
}

\author{
Ni Wayan Ariadi Putri, Kadek Widiantari \\ Program Studi D III Kebidanan, Politeknik Kesehatan Kartini Bali \\ Jl. Piranha No.2 Pegok Sesetan, Denpasar-Bali \\ E-mail : ${ }^{1)}$ ari_adiputri@yahoo.com
}

\section{Kata Kunci:}

Persepsi, Alat Kontrasepsi, Unmet Need KB

\begin{abstract}
ABSTRAK
Masih tingginya angka kejadian unmet need $\mathrm{KB}$ dimana muncul berbagai persepsi tentang alat kontrasepsi yang menjadi dasar seseorang untuk takut dalam menggunakan alat kontrasepsi dan hal ini pun yang dapat membuat tingginya angka unmet need tersebut. Desain penelitian ini adalah observasional analitik dengan pendekatan Crossectional. Populasi dalam penelitian ini adalah seluruh pasangan usia subur di wilayah Kota Denpasar periode tahun 2020 dan jumlah sampel dalam penelitian yaitu berjumlah 96 pasangan usia subur dengan menggunakan teknik proportional stratified random sampling. Data dikumpulkan dengan penyebaran kuesioner online dan d teknik analisis data yang digunakan adalah uji Chi-Square. Tujuan dalam penelitian ini adalah mengetahui hubungan persepsi pemakaian alat kontrasepsi dengan kejadian unmet need $\mathrm{KB}$ pada pasangan usia subur. Hasil penelitian ini didapatkan bahwa terdapat hubungan antara persepsi pemakaian alat kontrasepsi $(p=0,477)$ dengan kejadian unmet need KB pada pasangan usia subur. Hasil penelitian ini diharapkan menjadi referensi untuk membantu meningkatkan cakupan pemakaian alat kontrasepsi KB di Daerah Kota Denpasar.
\end{abstract}

\section{ABSTRACT}

The high incidence of unmet need for family planning is where there are various perceptions about contraceptives that become the basis for a person to be afraid to use contraceptives and this can also make the number of unmet need high. The design of this study was analytic observational with a cross-sectional approach. The population in this study were all couples of childbearing age in the Denpasar City area for the period of 2020 and the number of samples in this study amounted to 96 couples of childbearing age using the proportional stratified random sampling technique. Data was collected by distributing online questionnaires and the data analysis technique used was the Chi-Square test. The purpose of this study was to determine the relationship between perceptions of contraceptive use and the incidence of unmet need for family planning in couples of childbearing age. The results of this study found that there was a relationship between perceptions of contraceptive use $(p=0.477)$ and the incidence of unmet need for family planning in couples of childbearing age. The results of this study are expected to be a reference to help increase the coverage of contraceptive use in the Denpasar City area.

\section{PENDAHULUAN}

Berdasarkan hasil SDKI tahun 2012 terdapat angka unmet need di Indonesia masih tinggi yaitu sebesar 9,0\% [1]. Tingginya angka unmet need bukan hanya menjadi permasalahan dalam program Keluarga Berencana di Indonesia, namun juga dihadapai oleh tiap belahan dunia, sehingga perlu mendapatkan perhatian yang khusus.

Terdapat dua sisi dalam melihat kejadian unmet need yaitu sisi klien itu sendiri dan sisi penyedia pelayanan $K B[2]$. Apabila alat kontrasepsi ini tidak tersedia atau tidak sesuai dengan keinginan klien, maka dapat mempengaruhi keputusan klien untuk tidak 
menggunakan kontrasepsi. Dari sisi kebutuhan akan KB, dapat dilihat bahwa hal untuk mengatur jarak kelahiran ataupun merencanakan waktu yang tepat merupakan hal yang diinginkan oleh setiap individu maupun pasangannya. Peningkatan unmet need KB dipengaruhi oleh factor penentu, factor pemungkin dan factor pendorong. Faktor penentu meliputi sikap, pengetahuan, keyakinan, keprcayaan, pengalaman. Adapun factor pemungkin berupa sarana prasarana, keterjangkauan biaya,akses fasilitas, sumber informasi, keterpaparan nakes. Faktor pendorong yaitu dukungan suami dan keyakinan sosial budaya [3].

Berbagai upaya sudah dilaksanakan dari pihak BKKBN dalam menekan kejadian Unmet Need salah satunya dengan memberikan penyuluhan, pembagian kontrasepsi gratis, namun semua upaya yang dilakukan belum menunjukkan keberhasilan dalam menekan Unmet Need [4]. Ahasil studi pendahuluan dengan beberapa wanita usia subur di wilayah Kota Denpasar berpendapat bahwa alasan mereka tidak menggunakan KB karena takut akan efek samping yang ditimbulkan dalam menggunakan alat kontrasepsi.

Persepsi merupakan cara pandang seseorang terhadap suatu obyek atau peristiwa tertentu. Pada proses persepsi seseorang dituntut untuk memberikan penilaian baik yang bersifat positif maupun negatif. Persepsi juga dapat mempengaruhi dan mendorong seseorang untuk melakukan sesuatu. Adanya persepsi dapat membentuk suatu sikap untuk bertindak didalam situasi tertentu.[5] Persepsi dapat diartikan sebagai hasil interpretasi seseorang terhadap suatu obnjek yang cenderung bersifat subjektif, hal ini pun akan menjadi salah satu alas an sesorang dalam mengambil suatu keputusan.
Jenis-jenis alat kontrasepsi ada yang berupa pil, suntik, AKDR, implan dan kondom. Muncul beberapa keluhan dari masing-masing pemakaian alat kontrasepsi. Keluhan - keluhan berupa jadwal menstruasi yang tidak tepat tiap bulan, terjadi perdarahan diluar haid, berat badan bertambah, muncul flek-flek hitam di wajah, keluar bercak-bercak darah diluar jadwal haid dan tidak haid sama sekali. Berbagai keluhan yang muncul di masyarakat membuat Wanita yang sudah pernah menggunakan alat kontrasepsi untuk enggan memakai Kembali. Bahkan Wanita yang belum pernah menggunakan alat kontrasepsi pun menjadi takut dan cemas jika menggunakan alat kontarsepsi. Munculnya berbagai persepsi tentang alat kontrasepsi inilah menjadi dasar seseorang untuk takut dalam menggunakan alat kontrasepsi dan hal ini pun membuat tingginya angka unmet need [6].

Penelitian ini bertujuan untuk melihat hubungan persepsi pemakaian alat kontrasepsi terhadap kejadian Unmet Need pada pasangan usia subur di wilayah Kota Denpasar.

\section{TINJAUAN PUSTAKA}

Persepsi merupakan suatu proses yang berkaitan dengan stimulus yang dirasakan oleh individu melalui seluruh indera. Hal ini tidak berhenti sampai disitu, melainkan proses berlanjut yaitu dari hantaran stimulus-stimulus yang diterima.[7]

Adapun yang mengatakan bahwa persepsi adalah sebuah pengalaman dari objek-objek, peristiwa bahkan sampai hubungan-hubungan yang diperoleh yang kemudian disimpulkan atau ditafsirkan. [8] Tanggapan seseorang akan sesuatu hal yang muncul dalam ingatan dan berbentuk bayangan setelah kita mendapatkan suatu peristiwa.[9] 
Persepsi pada dasarnya masih terhubung dengan ingatan seseorang dalam mengingat nilai-nilai dari suatu objek dan juga pengetahuan seseorang. Hal ini pun akan berpengaruh jika pengetahuan dan informasi yang terkait tentang alat kontrasepsi kurang baik, maka hal ini pastinya dapat menimbulkan persepsi yang kurang baik juga tentang alat kontrasepsi.

Dalam menumbuhkan suatu persepsi sangat diperlukan konstansi terhadap suatu objek yang bersangkutan, agar persepsi yang ditimbulkan baik atau positif. [10]

Program Keluarga Berencana merupakan suatu upaya dalam meningkatkan rasa peduli serta peran dari masyarakat sekitar yang dilakukan melalui pengaturan usia perkawinan, pemberian jarak lahir, pembekalan perkawinan, peningkatan kesejahteraan keluarga kecil, bahagia dan sejahtera. Berbagai metode kontrasepsi :

1. Metode Sederhana, yaitu pantang berkala, metode kalender, suhu basaal, pengaturan lendir serviks, senggama terputus

2. Menggunakan Alat, yaitu kondom, pil, suntik, implant, AKDR, dan Kontrasepsi Mantap (MOW/MOP)

Penggunaan alat kontrasepsi postpartum juga belum banyak diminati. Hal tersebut dikarenakan faktor dari keinginan PUS lebih murah menggunakan metode sederhana seperti senggama terputus dan laktasi amenorre.[11] Ibu postpartum 6 minggu memiliki keinginan untuk menunda kehamilannya, tetapi disaat menentukan penggunaan metode kontrasepsi cenderung memilih penggunakan metode sederhana. Ibu postpartum yang berusia kurang dari 20 tahun, juga pendidikan yang kurang bahkan yang melaksanakan proses kelahiran dirumah merupakan orang-orang yang sangat kurang akan informasi mengenai alat-alat kontrasepsi dan tentunya semakin meningkatkan potensi kejadian unmet need.[12]

Putro dan Listiningtyas (2017) dalam penelitiannya mengatakan bahwa tingkat kejadian unmet need KB antara di desa dan di wilayah perkotaan tidak memiliki perbedaan yang bermakna dan jumlah wanita yang mengalami unmet need lebih banyak di perkotaan dengan karakteristik jumlah anak lebih dari 2 dan sebelumnya sudah pernah menggunakan alat kontrasepsi. Hal ini menjadi dasar bahwa pengalaman wanita tentang alat kontrasepsi KB baik pengalaman yang positif maupun yang negative akan berpengaruh terhadap persepsi pemakaian alat kontrasepsi wanita tersebut pada saat akan diharuskan menggunakan alat kontrasepsi kembali setelah kelahiran anak berikutnya.[13]

Hasanah (2016) dalam penelitiannya juga menyebutkan bahwa persepsi pemakaian alat kontrasepsi pada suami berhubungan terhadap keputusan pemakaian metode KB. Persepsi pemakaian alat kontrasepsi pada lakilaki dapat menjadi penentu pemakaian metode KB karena dalam berpasangan suami yang berperan $70 \%$ dalam pengambilan keputusan.[14]

Mawarni (2016) dalam penelitian menyatakan bahwa kejadian unmet need tidak berhubungan dengan persepsi akses pelayanan dalam berKB. Hal ini dikarenakan daerah kota tempat lokasi penelitian mudah dijangkau dengan pusat pelayanan kesehatan dan informasi kesehatan terkait keluarga berencana juga sudah banyak diberikan. Berbeda halnya jika tempat yang akan dilakukan penelitian ini terjauh dari pusat fasilitas kesehatan.[6]

Persepsi tentang pemakaian alat kontrasepsi pada pasangan usia subur memberikan sebuah pengalaman pada pasangan usia subur tentang pemakaian 
kontrasepsi sebelumnya, hal ini menunjang terhadap keinginin pasangan usia subur tersebut untuk mau lagi menggunakan alat kontrasepsi.

\section{METODE}

Penelitian ini merupakan penelitian observasional analitik dengan pendekatan cross sectional. Sampel dalam penelitian ini adalah pasangan usia subur yang berada di wilayah Kota Denpasar yang berjumlah 96 pasang. Teknik sampling penelitian yaitu stratified random sampling dengan instrument penelitian yaitu lembar kuesioner berupa google form. Data yang diambil dalam penelitian ini merupakan data primer. Teknik analisa penelitian menggunakan teknik chisquare.

\section{HASIL DAN PEMBAHASAN}

Tabel 1. Persepsi PUS terhadap Alat Konstrasepsi

\begin{tabular}{llcc} 
No & Katagori & Jumlah & Persentase \\
\hline 1 & Positif & 46 & 47,9 \\
\hline 2 & Negatif & 50 & 52,1 \\
\hline & Jumlah & 40 & 96
\end{tabular}

Berdasarkan tabel 1 menunjukkan bahwa responden pasangan usia subur sebagian besar yaitu 50 orang $(52,1 \%)$ memiliki persepsi yang negative terhadap pemakaian alat kontrasepsi. Hal sesuai dengan pendapat Kartini, bahwa persepsi yang muncul merupakan hasil ingatan suatu individu dalam memberikan suatu nilai terhadap suatu objek dan juga pengetahuannnya. Persepsi bisa mempengaruhi terhadap suatu keputusan seseorang tersebut.[10] Begitu pula halnya dalam pemakaian alat kontrasepsi, persepsi negative yang tinggi pada pasangan usia subur dikarenakan faktor pengetahuan yang kurang mengenai alat kontrasepsi yang dilihat dari efeksamping pemakaian, ketidaknyamanan setelah pemakaian, biaya yang harus dikeluarkan dan tujuan dari masing-masing alat kontrasepsi. Hal ini yang membuat pasangan usia subur menjadi kurang berminat akan pemakaian alat kontrasepsi.

Hal ini sesuai dengan penelitian Kesuma,dkk (2021) bahwa persepsi suami tentang pemakaian alat kontrasepsi dipengengaruhi oleh karakteristik dari individu tersebut yang terdiri dari pengetahuan, pendidikan, motivasi, minat, pengalaman, status ekonomi, tempat tinggal dan sosial budaya. Pada daerah perkotaan karakteristik pasangan usia subur yang heterogen yang terdiri juga dari latar pendidikan yang tidak merata, dan juga banyaknya latar belakang ekonomi yang masih rendah membuat pasangan tersebut tidak paham dan tidak focus pada pentingnya pemakaian alat kontrasepsi. Dari latar belakang ekonomi yang rendah juga membuat pasangan usia subur ini tidak mampu untuk membeli alat kontrasepsi.[15]

Dalam penelitian Sitorus dan Siregar (2017) menyatakan bahwa sebagian besar wanita usia subur memiliki persepsi tentang jumlah anak ideal $\geq 3$ sebesar $52 \%$. Persepsi wanita usia subur yang menyatakan jumlah anak yang lebih dari 3 membuat pasangan tersebut untuk enggan menggunakan alat kontrasepsi. Hal inilah yang membuat tingginya kejadian unmet need.[16]

Tabel 2. Hasil Uji Chi-square data Persespsi Pemakaian Alat Kontrasepsi dengan Kejadian Unmet Need KB

\begin{tabular}{|c|c|c|c|c|c|}
\hline \multirow[t]{3}{*}{ Katagori } & \multicolumn{4}{|c|}{ Kejadian Unmet Need } & \multirow[t]{3}{*}{$\mathbf{P}$} \\
\hline & \multicolumn{2}{|c|}{$\begin{array}{c}\text { Unmet } \\
\text { Need }\end{array}$} & \multicolumn{2}{|c|}{ Met Need } & \\
\hline & $\mathbf{F}$ & $\%$ & $\mathbf{F}$ & $\%$ & \\
\hline Persepsi & & & & & 0,041 \\
\hline a. Negatif & 30 & 60 & 20 & 40 & \\
\hline b. Positif & 18 & 39,1 & 28 & 60,9 & \\
\hline
\end{tabular}


Berdasarkan data di atas terlihat bahwa persepsi dengan nilai $\mathrm{p}=0,041(\mathrm{p}<0,05)$ yang bermakna bahwa terdapat hubungan bermakna antara persepsi dengan kejadian unmet need pada pasangan usia subur.

Persepsi menggambarkan hasil interpretasi seseorang terhadap sesuatu yang cenderung akan bersifat lebih subjektif. Keadaan diri pada seseorang dan kemampuan seseorang menganalisa suatu objek akan mempengaruhi persepsi tersebut.[17] Hal ini sesuai dengan penelitian Mayla, et al (2019) berpendapat bahwa ada pengaruh persepsi tidak nyaman oleh karena efek samping terhadap pemakaian alat kontrasepsi di wilayah Puskesmas Klabang Kabupaten Bondowoso. Hal tersebut merupakan penyebab dari kurangnya media informasi mengenai alat kotrasepsi yang disampaikan kepada wanita usia subur.[7] Semakin buruk pengalaman yang dialami oleh pasangan usia subur tentang pemakain alat kontrasepsi, , menyebabkan ketakutan kembali untuk menggunakan akibat ketidaknyamanan pemakaian alat kontrasepsi tersebut. Hal inilah yang menyebabkan semkain tingginya kejadian unmet need pada pasangan usai subur.

Persepsi pasangan usia subur akan pemakaian alat kontrasepsi juga dipengaruhi oleh anggapan jumlah anak ideal. Masyarakat umumnya memiliki anggapan bahwa keluarga yang ideal adalah keluarga yang memiliki anak $>3$ orang. Masih banyaknya anggapan bahwa memiliki banyak anak akan membuat banyak rejeki mengalir. Hal inil jelas akan membuat semakin banyak pasangan usia subur yang tidak memiliki keinginan untuk menggunakan alat kontrasepsi. [18] Munculnya persepsi yang negative pada pasangan usia subur, dikarenakan latar belakang pendidikan.[19] Informasi yang semakin lengkap tentang efek samping dari pemakain alat konstrasepsi dan resiko jarak anak terlalu dekat dan juga resiko anak terlalu banyak, hal ini membuat persepsi yang positif pada pasangan usia subur tersebut.[20] Berawal dari pernah menggunakan alat kontrasepsi juga memberikan pengalaman yang positif maupun yang negative. Pengalaman yang negative apabila tidak tertangani dengan baik oleh petugas kesehatan, dapat menjadi sumber informasi yang negative pula di masyarakat. Semakin negative informasi tentang alat kontrasepsi maka menyebabkan ketakutan untuk menggunakan alat kontrasepsi dan semakin tinggilah angka kejadian unmet need.

Kurangnya informasi pada pasangan usia subur, akan membuat persepsi yang salah terhadap pemakaian alat kontrasepsi. Ini pun tidak menjadi pembeda antara pasangan usia subur di perkotaan maupun di pedesaan.[13] Hal yang akan terjadi adalah semakin meningkatnya wanita usia subur untuk enggan menggunakan alat kontrasepsi atau semakin meningkatkan kejadian unmet need dan pastinya juga akan semakin memperbesar resiko kehamilan yang tidak diinginkan. Perihal hal tersebut menjadi tantangan bagi tenaga kesehatan, dimana sangat pentingnya komunikasi yang baik dalam melakukan konseling $\mathrm{KB}$ baik secara perseorangan maupun konseling berpasangan. Karena konseling yang baik dan mudah dipahami akan memberikan persepsi yang baik bagi pasangan usia subur.[21]

Dukungan suami dalam pengambilan keputusan sangat besar pengaruhnya dalam menentukan pemakaian alat kontrasepsi. Jika suami tidak paham dan mendapat informasi yang baik tentang alat-alat kontrasepsi, maka hal ini berhubungan dalam persepsi suami tentang alat kontrasepsi tersebut. Bahkan pasangan usai subur yang menjadi unmet need akan memiliki peluang dalam meningkatkan angka kelahiran yang nantinya dapat menjadi 
kekhawatiran negara akan terjadi ledakan penduduk. Penduduk di negara yang berkembang dan negara miskin menjadi penyumbang terbanyak terhadap angka kelahiran. [22]

Sumber media informasi juga menjadi salah satu sumber dalam memperoleh pengetahuan akan metode kontrasepsi. Banyak media yang kurang memberikan penjelasan yang secara umum dapat dipahami oleh masyrakat terkait tentang kontrasepsi yang lebih lengkap. Wanita yang memiliki ketakutan akan efek samping pun juga semakin meningkatkan kejadian unmet need.[23]

\section{KESIMPULAN}

Kesimpulan penelitian ini adalah terdapat hubungan yang bermakna antara persepsi pemakaian alat kontrasepsi dengan kejadian unmet need pada pasangan usia subur. Saran perlu adanya pelatihan dari petugas Kesehatan khususnya petugas lapangan $\mathrm{KB}(\mathrm{PL} \mathrm{KB})$ tentang Alat-alat kontrasepsi berserta efek sampingnya dan juga cara melakukan konseling yang baik.

\section{DAFTAR PUSTAKA}

[1] Kemenkes.RI, "Survei Demografi Kesehatan Indonesia," Jakarta,Indonesia, 2012.

[2] Budiman and R. A., Kapita Selekta Kuesioner Pengetahuan dan Sikap dalam Penelitian Kesehatan.

Jakarta,Indonesia: Salemba Medika, 2015.

[3] Y. Ulsafitri and N. R. Fastin, "FaktorFaktor Yang Berhubungan Dengan Unmet Need Kb Pada Pasangan Usia Subur (PUS).," J. Kebidanan Stikes Yars. SUMBAR Bukit tinggi,Vol.3 No.1., vol. 1, no. Volume 3, 2015.

[4] BKKBN, "Laporan Tahunan
Pelaksanaan Program Kependudukan KB dan Pembangunan Keluarga

Nasional di Provinsi Bali Tahun 2015," Denpasar, Bali, 2015.

[5] A. HUDA, ALIMATUL, R. S. Wardani, and I. A. Purwanti, "FAKTOR-FAKTOR YANG BERHUBUNGAN DENGAN KEJADIAN UNMET NEED KELUARGA BERENCANA DI PUSKESMAS BANDARHARJO KECAMATAN SEMARANG UTARA(Studi di Kelurahan Dadapsari)," 2016.

[6] atik mawarni, "HUBUNGAN PERSEPSI AKSES DAN PELAYANAN KB DENGAN KEJADIAN UNMET NEED," $J$. Penelit. Kesehat. "SUARA FORIKES" (Journal Heal. Res. "Forikes Voice”), vol. 7, no. 1, Jan. 2016, doi: $10.33846 / \%$.

[7] mayla evitasari, K. Kholisotin, and Y. D. Agustin, "PENGARUH EFEK SAMPING PENGGUNAAN KONTRASEPSI TERHADAP KEJADIAN UNMET NEED DI WILAYAH KERJA PUSKESMAS KLABANG KABUPATEN BONDOWOSO," Al-Asalmiya Nurs. J. Nurs. Sci., vol. 8, no. 1, pp. 53-65, Nov. 2019, Accessed: Jul. 30, 2021. [Online]. Available: https://jurnal.stikesalinsyirah.ac.id/index.php/keperawatan/ article/view/473.

[8] J. Rakhmat, Psikologi Komunikasi. Bandung: PT. Remaja Rosdakarya, 2015.

[9] S. Suryabrata, Psikologi Pendidikan. Jakarta,Indonesia: PT.Raja Grafindo Persada, 2013.

[10] K. Kartono, Kamus Lengkap Psikologi. Jakarta,Indonesia: PT.Raja Grafindo 
Persada, 2011.

[11] C. Rossier, S. E. K. Bradley, J. Ross, and W. Winfrey, "Reassessing Unmet Need for Family Planning in the Postpartum Period," Stud. Fam. Plann., vol. 46, no. 4, pp. 355-367, Dec. 2015, doi: $10.1111 / \mathrm{J} .1728$ 4465.2015.00037.X.

[12] O. Pasha et al., "Postpartum contraceptive use and unmet need for family planning in five low-income countries," Reprod. Heal. 2015 122, vol. 12, no. 2, pp. 1-7, Jun. 2015, doi: 10.1186/1742-4755-12-S2-S11.

[13] D. A. Putro and U. Listyaningsih, "UNMET NEED KELUARGA BERENCANA DI DAERAH PERKOTAAN DAN PERDESAAN DI PROVINSI DAERAH ISTIMEWA YOGYAKARTA," J. Bumi Indones., vol. 6, no. 4, 2017, Accessed: Aug. 05, 2021. [Online]. Available: http://lib.geo.ugm.ac.id/ojs/index.php/jb i/article/view/903.

[14] N. Hasanah, "PENGARUH PERSEPSI SUAMI TENTANG ALAT KONTRASEPSI DAN KETERLIBATAN ISTERI DALAM PENGAMBILAN KEPUTUSAN TERHADAP KEJADIAN UNMET NEED KB PADA PASANGAN USIA SUBUR (PUS) DI KECAMATAN BENJENG KABUPATEN GRESIK," Hosp. Majapahit (JURNAL Ilm. Kesehat. Politek. Kesehat. MAJAPAHIT MOJOKERTO), vol. 8, no. 2, Nov. 2016, doi: 10.5281/ZENODO.3514496.

[15] T. Kesuma Dewi, J. Purwono, and A. Keperawatan Dharma Wacana, "DETERMINAN PERSEPSI SUAMI TENTANG PENGGUNAAN ALAT KONTRASEPSI ANALISIS SDKI 2017," J. Wacana Kesehat., vol. 6, no.
1, pp. 15-22, Jul. 2021, doi: 10.52822/JWK.V6I1.168.

[16] M. Ancha Sitorus and P. A. Siregar, "PENGARUH FREKUENSI MEDIA DAN KETERPAPARAN INFORMASI TENTANG KB TERHADAP PERSEPSI JUMLAH ANAK IDEAL: ANALISIS DATA SDKI 2017," J. Kesehat., vol. 14, no. 1, pp. 62-70, 2021, doi: DOI: https://doi.org/10.24252/kesehatan.v14i 1.16929.

[17] Roeckelein and Jon E, Kamus Psikologi, Terjemahan. Jakarta,Indonesia: Kencana, 2013.

[18] M. A. Sitorus and P. A. Siregar, "PENGARUH FREKUENSI MEDIA DAN KETERPAPARAN INFORMASI TENTANG KB TERHADAP PERSEPSI JUMLAH ANAK IDEAL: ANALISIS DATA SDKI 2017," $J$. Kesehat., vol. 14, no. 1, pp. 62-70, Jun. 2021, doi:

10.24252/KESEHATAN.V14I1.16929.

[19] S. Sariyati, S. Mulyaningsih, and S. Sugiharti, "Faktor yang Berhubungan dengan Terjadinya Unmet Need KB pada Pasangan Usia Subur (PUS) di Kota Yogyakarta," J. Ners dan Kebidanan Indones., vol. 3, no. 3, pp. 123-128, Nov. 2015, doi: 10.21927/JNKI.2015.3(3).123-128.

[20] A. A. A. Ali and A. Okud, "Factors affecting unmet need for family planning in Eastern Sudan.," BMC Public Health, vol. 13, p. 102, 2013, doi: 10.1186/1471-2458-13-102.

[21] D. F. Paramita, Thohirun, and N. Baroya, "Hubungan antara Otonomi Perempuan dan Persepsi terhadap Pelayanan Konseling KB dengan Unmet Need KB pada Pasangan Usia Subur di Kecamatan Sumberjambe Kabupaten 
Jember (Association between Women's Autonomy and Perception of Counseling Services FP Spouses o," $e$ Jurnal Pustaka Kesehatan,Vol. 5, (No. 2), Mei2017, vol. V, pp. 214-222, 2017, Accessed: Aug. 05, 2021. [Online]. Available:

https://jurnal.unej.ac.id/index.php/JPK/a rticle/view/5490.

[22] J. K. Wulifan, S. Brenner, A. Jahn, and M. De Allegri, "A scoping review on determinants of unmet need for family planning among women of reproductive age in low and middle income countries," BMC Women's Heal. 2016 161, vol. 16, no. 1, pp. 1-15, Jan. 2016, doi: 10.1186/S12905-015-0281-3.

[23] M. F. Asif and Z. Pervaiz, "Sociodemographic determinants of unmet need for family planning among married women in Pakistan," BMC Public Heal. 2019 191, vol. 19, no. 1, pp. 1-8, Sep. 2019, doi:

10.1186/S12889-019-7487-5. 